\title{
AN ALTERNATIVE APPROACH TO MEET BEEF SELF-SUFFICIENCY IN WEST PAPUA
}

\author{
S. Hartono ${ }^{1}$ and T.W. Widayati ${ }^{1,2}$ \\ ${ }^{1}$ Faculty of Agriculture, Gadjah Mada University, \\ Jl Flora, Bulaksumur, Yogyakarta, 55281-Indonesia \\ ${ }^{2}$ Permanent Address: Faculty of Animal Husbandry, Fishery and Marine Science, \\ Papua University, Jl. Gunung Salju, Amban, Manokwari 98304 - Indonesia \\ Corresponding E-mail: trieswd@yahoo.com
}

Received April 18, 2011; Accepted August 22, 2011

\begin{abstract}
The main objective of this research is to present an alternative approach to meet beef selfsufficiency in West Papua, Indonesia. It mainly focuses on calculating the needed number of productive cows to enhance beef production in the province. Out of the total farmer households in Manokwari, Indonesia, 189 farmer-respondents were selected as samples of the study. Selection of the sample was based on the number of cattle kept in every age group (less than one $(<1)$ year old; one to two $(1-2)$ years old, and more than two $(>2)$ years old and the number of productive cows. Secondary data came from the time series data of the number of slaughtered cattle vis-à-vis the population of all districts in West Papua Province from 1980-2008. Data were analyzed using the Partial Adjustment Model (PAM) and Ordinary Least Square (OLS) method. Results of the study showed that beef self-sufficiency in West Papua depend on the availability of the number of productive cows to produce ready-slaughtered-bull in the previous year. Particularly for West Papua, to produce one unit of bull in the $t^{\text {th }}$-year, with the assumption that cattle mortality is $4.92 \%$, a number of 2.38 animal units $\mathrm{AU}$ of productive cows must be provided in the previous two (2) years.

Keywords: beef-self-sufficiency, Partial Adjustment Model (PAM), productive cow, readyslaughtered-bull
\end{abstract}

\section{INTRODUCTION}

The 2010 program beef self-sufficiency in Indonesia failed to be achieved and has been prolonged for 2014. The situation indicated that it is not easy to reach self-sufficiency condition and requires more detailed steps as far as farm management is concerned. Yusja and Ilham (2003) suggested that one of the weaknesses in cattle farm management in Indonesia is less population data. In relation to beef self sufficiency, Sumadi (2010) stated that the estimation was considered only on data in general, but did not describe about sex, age, stage and breed of cattle. Therefore, the number of productive cows is not accurately known so unable to calculate production capacity of total cows, how many ready-slaughtered-bulls in every year, and how much level of slaughtered cattle has been over or under the natural growth. It will be better if the composed population data can be presented in statistics report annually to facilitate all parties that have concerned to the beef self sufficiency target, participate for the self sufficiency program achievement.

Oetoro (1997) summarized that supply of beef cattle in Indonesia was come from three (3) main sources, namely traditional farm, industry and import. Sumadi (2010) stated that traditional farm holds $95.21 \%$ of the cattle supply. Therefore, self-sufficiency calculation should involve traditional farm as main contributor. Selfsufficiency management can be used to consider the consumption of a region with certain consumer coverage in every year and beef production capability in the region, particularly for traditional farm.

Papua is a potential area for beef cattle development because of its wide natural grazing land. In 2005, statistical data of West Papua indicated that production of forage and agricultural plantation waste products were $42,442.750$ ton from the area of 4,244.275 hectares. The feed production is able to supply for 
3,876,050 AU of beef cattle a year. Therefore, the availability of farm resources to supply feedstuff is a significant factor to support beef cattle development in West Papua Province.

West Papua population consists of various ethnics. Provincial which is further disaggregated by regions and districts influence the increasing of population. Population growth indicated increasing trend as a result of disaggregation in provincial and regency level. Population growth rate from 2003 to 2005 according to SUPAS (2005) reached $10.83 \%$, or there were 643,012 people in the province in 2005.

According to The BPS and BAPPEDA, data in 2009 showed that slaughtered cattle as expression of beef consumption during 2004 2008 increased about $114.38 \%$. The increase in consumption which is not balanced with the increasing of cow population is a challenge to seriously review the beef cattle management aspect. In order to regulate the balance between supply and demand of beef cattle, the production continuity and reaching of safety stock should be considered (Suryana, 2009). Therefore, a region should have beef cattle supply management. The most crucial thing has to be considered for the purpose in order to maintain a number of productive cows in every year as producer of bulls. Availability of detail population data base on sex, age, and breed cattle annually becomes very important to support this program. The main objective of this research is to present an alternative approach to meet beef self-sufficiency in West Papua, Indonesia.

\section{MATERIALS AND METHODS}

This research was conducted in West Papua Province, Indonesia. Data collection were both the primary and secondary data. The primary data was the number of male-cattle of $<1$ year old, 1-2 years old, and $>2$ years old, and number of productive cows of the farmer. There were 189 sample respondents of the farmer population in Manokwari District. Secondary data consisted of the time series of the number of slaughtered cattle and people population from 1980-2008 from all districts of West Papua Province. Data were analyzed by using the mathematics and econometrics equation models, especially the Partial Adjustment Model (PAM) and Ordinary Least Square (OLS) method.

There were three (3) steps to calculate the productive cows needed, those were: a) to make an estimation of beef needed in West Papua annually, b) to estimate the production capacity of domestic beef cattle farmer based on the productive cows ability to produce calves, and c) estimate the amount of productive cows that should be prepared in previous year which it will produce ready-slaughtered-bulls in West Papua.

\section{Estimation Procedure}

Step 1. Estimate the Number of Beef that Should be Produced Every Year according to People Population with PAM (Nerlove, 1972)

Record showed that during the period of 1980-2008, beef consumption in West Papua fluctuated. The correlation between beef consumption and population can be captured by OLS or PAM method. The PAM was used in this study because OLS method can not capture the dynamic response between the observed variable, and autocorrelation were expected to be obtained as a limitation (Jeffrey et al., 1983; Vanzetti et al., 2010). The equation of beef that should be produced every year according to people population using PAM can be written as follows:

$\hat{Y}_{\text {beef production(t) }}=\alpha_{0}+\alpha_{1} X_{\text {people population }(t)}+\mu_{t} \ldots$. (1) Where :

$\hat{Y}_{\text {beef production( }(t)}=$ expected beef production level in year $\mathrm{t}(\mathrm{kg})$.

$X_{\text {people population }(t)}=$ population in provincial level in year $\mathrm{t}$ (people)

$\alpha_{0}=$ Intercept, $\alpha_{1}=$ coefficient of population change and $\mu_{\mathrm{t}}=$ error

Because $\hat{Y}_{\text {beef production }(t)}$ cannot be observed directly, so adjustment coefficient score should be found firstly with the following mechanism: $Y_{\text {beef prod( }(t)}-Y_{\text {beefp prod(t-1) }}=\delta\left(\hat{Y}_{\text {beef prod( }(t)}-Y_{\text {beef prod }(t-1)}\right)+v_{t}$ $Y_{\text {beef prod( }(t)}=\delta\left(\hat{Y}_{\text {beef prod }(t)}-Y_{\text {beef prod(t-1 })}\right)+Y_{\text {beef prod(t-1 })}+v_{t}$ $=\delta \hat{Y}_{\text {beef prod }(t)}+(1-\delta) Y_{\text {beef prod }(t-1)}+v_{t}$

$=\delta\left(\alpha_{0}+\alpha_{1} X_{\text {people pop }(t)}+\mu_{t}\right)+(1-\delta) Y_{\text {beef prod }(t-1)}+v_{t} \ldots$ (2)

Where :

$\hat{Y}_{\text {beef prod( }(t)}=$ expected beef production level in year $\mathrm{t}(\mathrm{kg})$

$Y_{\text {beef prod }(t)}=$ actual beef production level in year $\mathrm{t}$ $(\mathrm{kg})$.

$\mathrm{Y}_{\text {beefprod(t-I) }}=$ actual beef production level in year $\mathrm{t}-$ $1(\mathrm{~kg})$

$\delta=$ short-term adjustment coefficient, and $v_{t}=$ error. So, equation for short term beef supply is

$Y_{\text {beef prod }(t)}=\delta \alpha_{0}+\delta \alpha_{1} X_{\text {people pop }(t)}+(1-\delta) Y_{\text {beef prod(t-1) }}+$ $\left(\delta \mu_{t}+v_{t}\right) \ldots \ldots \ldots \ldots \ldots \ldots \ldots \ldots \ldots \ldots \ldots . . .(3)$ (Nerlove, 1972).

Equation (3) can be solved by regression. The value of adjustment coefficient (d ) can be 
calculated after the value of period difference coefficient (1-d) has been known (Pindyck and Rubinfield, 1998). The value of $d$ is between zero and one. If $\delta=1$, it means that actual stock adjusts to desired stock instantaneously (in the same time period). On the other hand, if $\delta=0$, it means that nothing changes since actual stock at time $\mathrm{t}$ is the same as the previous one (Satria, 1999; Seay et al., 2004; Nmadu, 2010)

Parameter coefficients of $\mathrm{a}_{0}$ and $\mathrm{a}_{1}$ are found by dividing coefficient $\mathrm{da}_{0}$ with $\mathrm{d}$. After coefficients $a_{0}$ and $a_{1}$ have been known, long term optimal supply function can be made as equation (1). In rewritten equation (1):

$\hat{Y}_{\text {beef prod }(t)}=\alpha_{0}+\alpha_{1} X_{\text {people population }(t)}+\mu_{t}$

To predict long-term cow meat supply that adjusted with population, trend of increased population with Geometric Rate of Growth (Lembaga Demografi Indonesia, 2000) as follow: $P_{t}=P_{0}(1+r)^{t}$.

Where :

$\mathrm{P}_{\mathrm{t}}=$ population in year $(\mathrm{t})^{\mathrm{th}}, \mathrm{P}_{\mathrm{o}}=$ the population of the early years, $r=$ rate of population growth in West Papua, $t=$ Year into its $1,2,3$ etc. Value $\mathrm{P}_{t}$ in equation (4), will be used for value $X_{\text {people(t) }}$ in equation $(1), P_{(t)}=X_{\text {people pop }(t)}$

The tested hypothesis is that increasing population and time-lag influence beef supply level in West Papua province. Ordinary Least Square method can be used to estimate the PAM equation when its error variable is $v_{t}=$ $\delta e_{t}$, where $0<\mathrm{d} \leq 1$, and when $e_{t}$ meet the classical assumption of Ordinary Least Square which are the error variable $v_{t}$ have homoschedastic characteristic and there is no autocorrelation (Nerlove, 1972, Hendayana, 2005, Widarjono 2007).

\section{Step 2. To Identify Production Capacity of Domestic Cattle Farm.}

Identification of production capacity of domestic cattle farm was done by viewing correlation between amount of productive cows (PC) as production machine and calf as output produced in one year in West Papua as follows:

1. Relationship between cattle under one year old with productive cow

$Y_{\text {bull under } 1 \text { year }}=\beta_{0}+\beta_{1} P C+v$

2. Relationship between bulls $1-2$ years old with productive cow

$Y_{\text {bull 1-2 years }}=\beta_{0}+\beta_{1} P C+v$
3. Relationship between bulls more than 2 years old with productive cow

$Y_{\text {bull }>\text { 2years }}=\beta_{0}+\beta_{1} P C+v$

From equation in step 2 , will be known multiplying coefficient of productive cow to produce calves. By comparing output requirement obtained in step one it will be known amount of productive cow that should be available to obtain the required output.

Cattle production cycle is relatively long. To produce one bull-reach-slaughter weight, a productive cow needs approximately three (3) years. Male calf will reach slaughter-weight (to be bull) in 2-3 years of age, while female calf be prepared as productive cow candidate at 1.8-2 years old and will be slaughtered at more than 8 years old (Bandini, 2003). Considering the matter, equation of calf and productive cow correlation should involve a dynamic regression equation (Widarjono, 2007), and involve certain time duration. Due to limited detail of annually cattle population data consisted of sex and age information, beef self sufficiency planning approach can be started with cattle data at current year by considering correlation between amount of productive cows and calves from cattle farmer household as a year $(\mathrm{t})$ data.

By using the year $(\mathrm{t})$ data, the following approach can be used.

$Y_{\text {bull under } 1 \text { years old }(t)}=\beta_{0}+\beta_{1} P C_{(t)}+v$

equivalent with

$Y_{\text {bull }>2 \text { years }(t+2)}=Y_{\text {bull ready slaughter }(t+2)}=\beta_{0}+\beta_{1} P C_{(t)}+v$

equivalent with

$Y_{\text {bull }>2 \text { years }(t)}=Y_{\text {bull ready slaughter }(t)}=\beta_{0}+\beta_{1} P C_{(t-2)}+v$

Given the mortality rate of cattle, the equation becomes

$Y_{\text {bull }>2 \text { years }(t)}=Y_{\text {bull ready slaughter }(t)}=\left(\frac{100-m}{100}\right)+\left(\beta_{0}\right.$

$\left.+\beta_{1} P C_{(t-2)}\right)$

Where :

$Y_{\text {bull under } 1 \text { year }(t)}=$ bull under one year old that be produced in year $\mathrm{t}$,

$Y_{\text {bull }>2 \text { years }(t)}=$ bulls older than two years,

$Y_{\text {bull ready slaughter(t) }}=$ bulls which is ready to be slaugtered , $m=$ mortality rate $(\%), P C_{(t-2)}=$ productive cows which invested in $(\mathrm{t}-2)$

It can be made a hypothesis that amount of ready slaughtered cattle at year(t), was influenced by the amount of invested productive cows in the 
two years previously.

Step 3: Calculating the Amount of Productive Cows Needs, Based on the Amount of Beef Needs to be Produced in Five Years.

The calculation result in step one and step two is used any furthure to calculate the need of production cattle in five years.

\section{RESULTS AND DISCUSSION}

\section{Analysis Result of Step 1}

The regression of PAM (equation 3) is presented in Table 1 . The Adj- $\mathrm{R}^{2}$ value of 0.832 indicated that from the explanatory variables (population and beef-production-lag) can explain $83.2 \%$ of beef production in year $t$, and the remaining $16.8 \%$ is explained by other variable. Table 1 shows population and beef consumption in previous year ( $\mathrm{t}-1)$ affect the beef production in year $t$ significantly ( $99 \%$ significance level). It agreed with the study of Arifin (2005) and De Silva et al. (2010) that explained that population influenced beef production and beef consumption significantly.

The short term change coefficient $(d)$ and long-term coefficient $\left(a_{0}\right.$ and $\left.a_{1}\right)$ can be calculated with the following way:

$(1-\delta)=0.686$,

$\delta \quad=0.308$

$\alpha_{0} \quad=-2330.091 / 0.308=-7565.23051$

$\alpha_{1} \quad=0.007 / 0.308=0.022727$

Then, $\mathrm{a}_{0}$ and $\mathrm{a}_{1}$ scores can be used as coefficient in long term equation as follows:

$$
\hat{Y}_{\text {beef prod }(t)}=-7565.23+0.022727 \mathrm{X}_{\text {people pop }(t)} \text {..... }
$$

The equation (12) can be used to estimate the beef production in the future years, by entering the value of $\mathrm{X}$ that come from the population trend in 2009 to 2014 (from equation 4). The result of equation (12) is presented in Table 2, column $\mathrm{b}$ and $\mathrm{c}$.

Table 2 shows estimated population in 2014 will be 805,406 people who need the ready slaughtered bulls of 10,739.23 animal units (AU). The average weight of in each cattle unit in West Papua as result of this study is $80 \mathrm{~kg}$, so the need of beef consumption in West Papua is 859,138.4 $\mathrm{kg}$. By knowing the need of beef consumption in West Papua it may help local government to plan in reaching the beef self sufficiency every year.

The cattle data which consists of age and sex information in West Papua resulted in this study is
Table 1. The Result of PAM Regression

\begin{tabular}{lrc}
\hline Parameter & Coefficient & Significance \\
\hline$\delta \alpha_{0}$ & -2330.091 & \\
$\delta \alpha_{0}$ & 0.007 & $* *$ \\
$(1-\delta)$ & 0.686 & $* *$ \\
$\mathrm{R}^{2}$ & 0.844 & \\
Adj R & 0.832 & \\
F.test (Sig.) & 0 & $* *$ \\
\hline$* *$ significant $(\mathrm{p}<0.01)$ &
\end{tabular}

presented in Table 3. Table 3 shows that not all of cattle are ready to be slaughtered in the same year. Total cattle in the sampled cattle from small holder farmer were 1.005 heads, and only $12.34 \%$ of them ready to be slaughtered. Average age of bull ready to be slaughtered were 24- 30 months (Park et al., 2002). Slaughter age of Bali bull in West Papua is at least 2 years old, and Bali cow is about 8 years old.

The current data published by BPS or Ministry of Agricultural so far did not describe the amount of ready slaughter cattle. Beef cattle population in West Papua in 2008 was 35.297 heads, but it was not known the proportion of mature cattle or ready to be slaughtered cattle. To manage regional and national beef sufficiency, the detail composed data of cattle consisted of sex and age should be provided. Considering the fact that to produce ready slaughtered cattle it takes several years, it is better if the composed data is presented annually. In addition, the breed differences will affect production level (Rumph and Vleck, 2004; Raphaka and Dzama, 2009), therefore the cattle population census must include breed of the cattle in the list (for example: Ongole, Bali, Simental, Limosin, etc.).

\section{Analysis Results of Step 2}

The production capacity of domestic cattle farmer was estimated through regressing productive cows as independent variable and cattle output (calves of breeding results) as dependent variable. Regression results are presented in Table 4.

Result of regression in Table 4 indicated that the best statistical score is on regression of productive cows and calves ( $<1$ year), either for male or female. It is marked with the highest of 0.821 and 0.737 . It reveals that in farmers group there was not significantly change amount of cattle sold or moved away from farmer household. 
Table 2. Population Trend in 2009-2014 and Prediction of Beef Needs Every Year

\begin{tabular}{cccc}
\hline Year & $\begin{array}{c}\text { Population of } \\
\text { West Papua(person) }\end{array}$ & $\begin{array}{c}\text { Prediction of beef need in year t } \\
\text { (Animal Unit) }\end{array}$ & Prediction of beef need (kg)* \\
\hline 2009 & 742,536 & 9310.39 & $744,831.2$ \\
2010 & 755,110 & 9596.16 & $767,692.8$ \\
2011 & 767,684 & 9881.92 & $790,553.6$ \\
2012 & 780,258 & 10167.69 & $813,415.2$ \\
2013 & 792,832 & 10453.46 & $836,276.8$ \\
2014 & 805,406 & 10739.23 & $859,138.4$ \\
\hline
\end{tabular}

*) column c x $80 \mathrm{~kg}$

Table 3. Composition of Cattle Population According to Sex and Age in West Papua.

\begin{tabular}{llcc}
\hline \multicolumn{1}{c}{ Cattle Age } & Sex & Amount $($ head $)$ & Percentage \\
\hline $0-1$ years old & Male & 136 & 13.53 \\
$0-1$ years old & Female & 137 & 13.63 \\
$>1-2$ years old & Male & 110 & 10.95 \\
$>1-2$ years old & Female & 133 & 13.23 \\
$>2$ years old & Male & 124 & 12.34 \\
$>2$ years old & Female & 365 & 36.32 \\
\multicolumn{1}{c}{ Total } & & $\left.1005^{*}\right)$ & $100.00 *)$ \\
\hline
\end{tabular}

*) All cattle are Bali breed

Table 4. Regression Results of Calves and Productive Cows (PC)

\begin{tabular}{lccccc}
\hline \multirow{2}{*}{ Correlation between } & \multicolumn{2}{c}{ Coefficient } & \multirow{2}{*}{$\mathrm{R}^{2}$} & $\operatorname{AdjR}^{2}$ & Significance \\
\cline { 2 - 3 } & $\beta_{0}$ & $\beta_{1}$ & & & \\
\hline Bull < 1 years old PC & -0.134 & 0.442 & 0.822 & 0.821 & $* *$ \\
Cow < 1 years old - PC & -0.015 & 0.383 & 0.736 & 0.737 & $* *$ \\
Bull 1-2 th - PC & 0.81 & 0.260 & 0.558 & 0.555 & $* *$ \\
Cow 1-2 th - PC & 0.56 & 0.335 & 0.600 & 0.598 & $* *$ \\
Bull > 2 th - PC & 0.440 & 0.112 & 0.137 & 0.133 & $* *$ \\
\hline
\end{tabular}

$* *=$ significant $(\mathrm{p}<0.01$

Meanwhile, statistic for regression of more than 2 years old male cattle (bull $>2$ years old) and productive cows had the lowest statistic score, with $\operatorname{AdjR}^{2}$ was only 0.133 . It can be understood that in this condition, many mature cattle have been sold or slaughtered so they cannot describe the real production correlation between the productive cows and calves. Based on the results, in relation to beef sufficiency planning, regression between productive cows and calves under 1 year old can be considered as a simple way to identify the ability of productive cows to produce calves.

Regression coefficient $\left(\beta_{1}\right)$ of productive cow as independent variable to the bull under one year as dependent variable is 0.442 (showed in Table 4.). By using mathematic operation, the $\beta_{1}$ value is used to fulfill the equation (8), and can be written as:

$Y_{\text {bull under } 1 \text { years old }(t+0)}=-0.134+0.442 \mathrm{PC}_{t}$

It is known that male calf (age <1 year old) is ready to be slaughtered after 2 years old 
Table 5. Estimation of Beef Need and Number of Productive Cow that Should be Provided Every t-2 with $4.92 \%$ Mortality Assumption

\begin{tabular}{cccccc}
\hline $\begin{array}{c}\text { Year } \\
\text { (t) }\end{array}$ & $\begin{array}{c}\text { Prediction need of } \\
\text { ready slaughtered } \\
\text { bulls every year } \\
\text { (Animal Unit) }\end{array}$ & $\begin{array}{c}\text { Prediction need of bulls } \\
\text { should be produced in } \\
\text { the two year previously } \\
\text { (Animal Unit)**) }\end{array}$ & $\begin{array}{c}\text { Year } \\
(\mathrm{t}-2)\end{array}$ & $\begin{array}{c}\text { Productive Cows } \\
\text { should be prepare in the } \\
\text { year } \\
\text { (t-2)th with 4.92\% } \\
\text { mortality cattle rate***) }\end{array}$ & $\begin{array}{c}\text { Ratio of bull } \\
\text { ready } \\
\text { slaughter } \\
\text {-PC (e/b) }\end{array}$ \\
\hline 2009 & 9310.39 & 9792.164493 & 2007 & 22154.52148 & 2.38 \\
2010 & 9596.16 & 10092.72192 & 2008 & 22834.51565 & 2.38 \\
2011 & 9881.92 & 10393.26883 & 2009 & 23514.48603 & 2.38 \\
2012 & 10167.69 & 10693.82625 & 2010 & 24194.48021 & 2.38 \\
2013 & 10453.46 & 10994.38368 & 2011 & 24874.47438 & 2.38 \\
2014 & 10739.23 & 11294.9411 & 2012 & 25554.46856 & 2.38 \\
\hline
\end{tabular}

*) result of step one, Table 2 . column c.

$* *$ ) from equation (17)

***) from equation (18)

(Bandini, 2003), so the equation (13) can be developed as :

$Y_{\text {bull under } 1 \text { years }}=Y_{\text {bull }>2 \text { years }(t)}=Y_{\text {bull ready slaughter }(t)}=$

$0.134+0.442_{t-2}$

Equation (14) showed that the amount of calves under one year old born during year $(\mathrm{t}-2)$ will be bulls two years old or more at year $(t)$, and to be bull ready to be slaughtered in the year ( $t$ ). To get value of productive cows (PC), the equation (14) can be developed and restructured as: $\mathrm{PC}(\mathrm{t}-2)=\frac{\left(0.134+Y_{\text {bull.ready.slaughter }}\right)}{0.442}$

Given the mortality rate of cattle in West Papua is $4.92 \%$, the equation (14) become:

$$
\begin{aligned}
& Y_{\text {bull }>2 \text { years }}=Y_{\text {bullready slaughter }(t)}=. \\
& \left(\frac{100-4.92}{100}\right)\left(-0.134+0.442 \mathrm{PC}_{(t-2)}\right)
\end{aligned}
$$

Because of $\quad Y_{\text {bull under 1year }(t-2)}=Y_{\text {bull produced }(t-2)}=$.

$$
\left(\frac{100}{100-4.92}\right) Y_{\text {bull ready slaughter }(t)}
$$

So equation(15) is developed as :

$$
\begin{aligned}
& \mathrm{PC}_{\mathrm{MR}(\mathrm{t}-2)}=\frac{\left(0.134+Y_{\text {bull.produced }}(t-2)\right)}{0.442} \ldots \ldots . .(18) \\
& \text { or : } \\
& \mathrm{PC}_{\mathrm{MR}(\mathrm{t}-2)}=\frac{\left[0.134+\left(\left(\frac{100}{(100-4.92)} Y_{\text {bull.ready.slaughter }}\right)\right)\right]}{0.442}
\end{aligned}
$$

Where :

$\mathrm{PC}_{\mathrm{MR}(\mathrm{t}-2)}=$ Productive cows that should be available in year ( $\mathrm{t}-2)$ with the assumption of
$4.92 \%$ cattle mortality assumption.

\section{Analysis Results of Step 3}

Result of step one (Table 3, column c) is used to fulfill Table 5 column b to calculate the need of productive cows amount to produce ready slaughtered cattle every year based on production capacity of productive cows in West Papua (equation 18 or 19). The calculation result is presented in Table 5.

Table 5 shows that to produce one ready slaughtered bull in year $\mathrm{t}$ using $4.92 \%$ cattle mortality assumption, it requires 2.38 units of productive cows that should be provided in year $(\mathrm{t}-2)$. The ratio between the bull and the productive cows above is just the lowest value to reach equilibrium of beef self-sufficiency in West Papua. The value can be increased based on some consideration such as importance to achieve surplus production or other economic consideration.

\section{CONCLUSION}

Beef self-sufficiency, as equilibrium of beef demand and supply, could be estimated if it is supported by accurate data on people population, amount of slaughtered cattle, and cattle population information i.e. sex, age, and type of breed. With the assumption of cattle mortality at $4.92 \%, 11,294.94$ AU of cattle should be produced by 2012. The productive cows should be 25,554.46 AU. This means that to produce one ready slaughtered bull ( $>2$ years old age) in year 
(t), and at $4.92 \%$ mortality assumption, it will require $2.38 \mathrm{AU}$ of productive cow that must be provided in the previous two (2) years.

\section{REFERENCES}

Arifin, Z. 2005. Analisis Penawaran Sapi Potong dan Sapi Bibit di Provinsi Nusa Tenggara Barat. Thesis. Faculty of Agriculture. Gadjah Mada University, Yogyakarta.

Bandini, Y. 2003. Sapi Bali. Penerbit Penebar Swadaya. Yogyakarta.

De Silva, P.H.G.J. , N.S.B.M. Atapattu and A.L. Sandika. 2010. A Study of The SocioCultural Parameters Associated With Meat Purchasing and Consumption Pattern: A Case of Southern Province, Sri Lanka. J. Agri. Sci 5(2):71-79

Hendayana, R. 2005. Penggunaan "Partial Adjusment Model" Sebagai alternatif alat daya saing komoditas Pertanian dalam Perdagangan Internasional. J. Socio Econ. of Agric. and Agribusiness (Soca). 5(2):1-18

Jeffrey, T., La France and O. R. Burt. 1983. A Modified Partial Adjustmen Model of Agregate U.S Agricultural Supply. Western J. Agric.Econ.8(1):1-12

Lembaga Demografi FE UI. 2000. Dasar-Dasar Demografi. Edisi 2000.Lembaga Penerbit FE UI, Jakarta

Nerlove, M.1972. Lag in Economic Behaviour. Econometrica. 40:221-251.

Nmadu, J. N. 2010. Revision of the Nerlovian partial adjustment framework and its application to sorghum production in Nigeria. African J. Agric. Res. 5(5):325-331.

Oetoro. 1997. Peluang dan Tantangan Pengembangan Sapi Potong. Prosiding Seminar Nasional Peternakan dan Veteriner. Pusat Penelitian dan Pengembangan Pertanian. Departemen Pertanian. Bogor 7-8 Januari 1997. p.87-95.

Park, G. B., S. S. Moon, Y. D. Ko, J. K. Ha, H. H. Chang and S. T. Joo. 2002. Influence of slaughter weight and sex on yield and quality grades of Hanwoo (Korean native cattle) carcasses. J. Anim. Sci. 80:129-136.

Pindyck, R.S. and D.L. Rubinfeld. 1998. Econometric Models and Economic Forecasts. Fourth Edition, McGraw-Hill, Singapore. P.442-462.

Raphaka, K and K. Dzama. 2009. Sex of calf and age of dam adjustment factors for birth and weaning weight in Tswana and Composite beef cattle breeds in Botswana South African J. Anim. Sci. 39(4):298-300

Rumph, J.M. and L.D Van Vleck. 2004. Age-ofdam adjustment factors for birth and weaning weight records: A review. Genet. Molec. Res. 3(1)1-17.

Sumadi. 2010. Productivity and development of beef cattle in Central Java. Prosiding Seminar Nasional Ruminansia 2010 Faculty of Animal Agriculture, Diponegoro University,.Central Java-Indonesia .Oct 6, 2010. p.1-2.

Suryana. 2009. Pengembangan usaha ternak sapi potong berorientasi agribisnis dengan pola kemitraann. J. Litbang Pertanian. 28(1): 2937

Seay, S.S., S.T. Pitts and R.H.Kamery. 2004. An explanation of the partial adjustment adaptive expextation (PAAE) model. Proceedings of the Academy for Economics and Economic Education. Allied Academies International Conference, New Orleans, Louisiana, April 7-10, 2004. P.55-60

Vanzetti, D., N.R. Setyoko, R.Trewin and R. Permani. 2010. The revival of interest in self-sufficiency in Indonesia and its likely consequences. Contributed paper at the Thirteen Annual Conference on Global Economic Analysis .Penang, Malaysia, June 9-11, 2010. p. 1-22.

Widarjono, A. 2007. Ekonometrika: Teori dan Aplikasi. Untuk Ekonomi dan Bisnis. Ekonesia. Economic Faculty, UII. Yogyakarta. 